\title{
Factors Affecting Herbivory of Thrips palmi (Thysanoptera: Thripidae) and Aphis gossypii (Homoptera: Aphididae) on the Eggplant (Solanum melongena)
}

\author{
Germano Leão Demolin Leite ${ }^{1 *}$, Marcelo Picanço ${ }^{2}$, José Cola Zanuncio ${ }^{2}$ and Carvalho \\ Carlos Ecole ${ }^{3}$ \\ ${ }^{1}$ Núcleo de Ciências Agrárias; Universidade Federal de Minas Gerais; CP: 135; gldleite@ufmg.br; 39404-006; \\ Montes Claros - MG - Brasil. ${ }^{2}$ Departamento de Biologia Animal; Universidade Federal de Viçosa; \\ zanuncio@mail.ufv.br; 36571-000; Viçosa - MG - Brasil. ${ }^{3}$ Universidade Federal de Viçosa; 36571-000; Viçosa - \\ $M G$ - Brasil
}

\begin{abstract}
The objective of this study was to evaluate effects of total rainfall, mean temperature, natural enemies, chemical composition of leaves, levels of nitrogen and potassium on leaves and density of leaf trichomes on attack intensity of Thrips palmi Karny (Thysanoptera: Thripidae) and Aphis gossypii (Glover) (Homoptera: Aphididae) on plantations of the eggplant (Solanum melongena) in two regions of Minas Gerais, Brazil. Higher numbers of A. gossypii/leaf

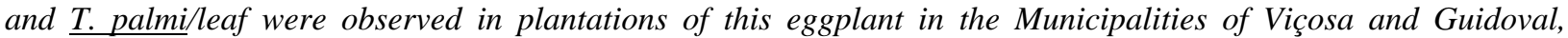
respectively. Guidoval had a rainy and hotter weather than Viçosa. T. palmi was almost positivelly correlated with rainfall ( $r=0.49, P=0.0538)$ while A. gossypii seemed to be more affected by mean temperature $(r=-0.31 ; P=$ 0.1134). Higher number of aphids in eggplants in Viçosa than in Guidoval could be explained by the higher number of natural enemies such as Adialytus spp. (Hymenoptera: Braconidae), Cycloneda sanguinea (L.) and Exochomus bimaculosus Mulsant (Coleoptera: Coccinellidae) and Chrysoperla spp. (Neuroptera: Chrysopidae) in this municipality. However, only Adialytus spp. was significativelly correlated with aphid populations. Higher number of

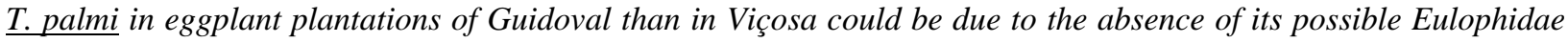
parasitoid in the first municipality. The spiders were significativelly correlated with this pest in both municipalities.
\end{abstract}

Key word: Aphis gossypii, natural enemies, plant nutrition, Solanum melongena, Thrips palmi

\section{INTRODUCTION}

The eggplant (Solanum melongena) is a tropical and subtropical plant growing in high temperatures which can produce up to $15 \mathrm{~kg}$ of fruit/plant (Filgueira, 2000). Among pests of this crop, the aphids Aphis gossypii (Glover) (Homoptera: Aphididae) and the thrips Thrips palmi Karny (Thysanoptera: Thripidae) (Etienne et al., 1990; Hosoda et al., 1993; Kajita et al.,
1996) are very important. Eggplants when severely attacked by thrips present leaves with small size and silver appearance and deformed fruits (Kawai, 1986; Sakimura et al., 1986; Gallo et al., 2002). Aphid attack causes severe damage to eggplant by feeding on sap, rolling leaves, and secreting honeydew (Hosoda et al., 1993; Gallo et al., 2002).

In different crops, T. palmi and A. gossypii have been controlled primarily with insecticides

\footnotetext{
${ }^{*}$ Author for correspondence
} 
(Hosoda et al., 1993; Kajita et al., 1996), but the extensive use of these pesticides can promote negative impacts on human health and on ecosystems, besides reducing the number of species and density of natural enemies, developing resistance and increasing production costs (Etienne et al., 1990; Nagai, 1990; Hosoda et al., 1993; Kajita et al., 1996). One of the main reasons for the extensive use of insecticides is the lack of informations about factors affecting insect pest control. Such informations could be used to predict attack rates by these insects which could reduce economic losses (Dent, 1995).

Several factors can influence population density of aphids and thrips on eggplants. Temperature and rainfall have been cited as the most important (Walker et al., 1984; Etienne et al., 1990; Nakata, 1995; Kajita et al., 1996), fertilization levels, presence of trichomes and natural enemies. According to Marschner (1995), excess of nitrogen $(\mathrm{N})$ and deficiency of potassium $(\mathrm{K})$ can increase the accumulation of amino acids, allowing the increase in sucking insect population on plants. Trichomes can also negatively affect, by chemical and/or mechanical ways, thrips and aphids populations (Dent, 1995). Natural enemies can also play an important role on the control of these pests on plants (Dent, 1995).

The objective of this study was to evaluate effects of total rainfall, mean temperature, predators and parasitoids, chemical composition of leaves, levels of $\mathrm{N}$ and $\mathrm{K}$, density of leaf trichoms and plant age on attack rate of $A$. gossypii and $T$. palmi in five eggplant plantations in two municipalities of Southwest region of Brazil.

\section{MATERIAL AND METHODS}

This experiment was conducted in two eggplant plantations in the municipality of Viçosa, Minas Gerais, Brazil (20 $44^{\prime} 38.7^{\prime \prime} \mathrm{S}, 42^{\circ} 49^{\prime} 18^{\prime \prime} \mathrm{W}$ and $649 \mathrm{~m}$ ), from February to July and from October to December of 1999, and three eggplant plantations in municipality of Guidoval, Minas Gerais, Brazil $\left(21^{\circ} 08^{\prime} 36^{\prime}\right.$ 'S, 42 $47^{\prime} 54^{\prime \prime} \mathrm{W}$ and $239 \mathrm{~m}$ ), from October to December of 1998 and from October to December of 1999. All eggplant plantations was of Solanum melongena var. "Natu Nobilis". Cultural practices used in this study were described by Filgueira (2000). Each eggplant plantation had 600 plants, spaced from $1.0 \mathrm{~m}$ within rows and $1.5 \mathrm{~m}$ between rows. The four outermost rows in each plot and the first ten plants in each side of the rows formed the surrouding border while data were collected from plants in the centre.

The number of aphids, thrips, predators and parasitoids per leaf of 10 plants/plantation was obtained monthly in Guidoval and weekly in Viçosa with the beating tray method (Butler et al., 1993; Stansly, 1995; Miranda et al., 1998a). This method consisted of beating the first expanded leaf of the upper part of plants in a $34 \times 26 \times 5 \mathrm{~cm}$ white tray, and then counting insects present. The insects were collected with an aspirator or with tweezers and individually placed in $8 \times 2 \mathrm{~cm}$ glass flasks containing $70 \%$ ethanol.

Trichome density was evaluated in one leaf from the apical part of the canopy of 10 plants/plantation, monthly collected in both municipalities. The colleted leaves were placed in white transparent plastic bags, immediately sealed, and transported to the laboratory. In the laboratory, these leaves were placed in to $10 \mathrm{~cm} \mathrm{x}$ $4 \mathrm{~cm}$ glass tubes containing $70 \%$ ethanol for later use. They were cleared for $2 \mathrm{~h}$ in $\mathrm{NaOH}(10 \%)$ and for $18 \mathrm{~h}$ in sodium hypochlorite $(20 \%)$ before analysis. This material was stained for three min by immersion in fast green after washing and during dehydration (Johansen, 1940) and mounted between slides with Canadian balsam. Trichomes $/ \mathrm{mm}^{2}$ (adaxial and abaxial) were counted under a microscope in 24 fields (area of one field $=0.60 \mathrm{~mm}^{2}$ ) in the central part (a field equidistant between the principal vein and the margin) of each leaf collected (Leite et al., 1999). Trichomes were classified according to Metcalfe and Chalk (1979). Three evaluations were made per month for each of the three plantations.

Level of $\mathrm{N}$ and $\mathrm{K}$ in leaves of the eggplant was estimated in laboratory condition in one expanded leaf from the upper part of each of 10 plants/plantation, collected monthly in both Municipalities. These leaves were placed in Kraft paper bags, dried in forced air circulation with temperature over $67^{\circ} \mathrm{C}$ during three days and then ground in a Wiley mill (20 mesh). Level of $\mathrm{K}$ was determined with Flame Photometer (Coleman, Model 22) and $\mathrm{N}$ was analysed with the Nessler method (Jackson, 1958). Three evaluations were made for each month for three plantations.

The gas chromatograph/mass spectrometer (GC/MS) analysis was developed, in 1999, with fully expanded leaves from the upper part of 10 plants/plantation, monthly collected in both 
municipalities. The leaves were collected and placed in plastic bags, sealed and transported to the laboratory. Fresh leaves $(10 \mathrm{~g})$ were cut and immersed in a $100 \mathrm{~mL}$ bidistilled hexane $(24 \mathrm{~h})$. The hexane extract was dehydrated with anhydrous $\mathrm{Na}_{2} \mathrm{SO}_{4}$, evaporated to dryness at $30^{\circ} \mathrm{C}$ in a rotatory evaporator, sealed in nitrogen and freezer stored until analysis. One evaluation was monthly carried out for each one of these three plantations.

The hexane extract was analysed by GC/MS (Shimadzu, Model QP 5000) composed by an auto sampler, a computer based system to accumulate data, and a mass spectra database (John Wiley) with 160,000 compounds in the following conditions: initial temperature $\left(33^{\circ} \mathrm{C}\right)$, then programmed at $80^{\circ} \mathrm{C}$ to $20^{\circ} \mathrm{C} / \mathrm{min}$, and finally at $250^{\circ} \mathrm{C}$ to $5^{\circ} \mathrm{C} / \mathrm{min}$. Injector and transfer line temperatures were 180 and $230^{\circ} \mathrm{C}$, respectively. The split ratio was five with $\mathrm{He}$ gas as the carrier. All analyses were carried on a DB1 fused capillary column ( $\mathrm{J}$ and W Scientific, USA, $30 \mathrm{~m}$ x $0.25 \mathrm{~mm}$ and film thickness of $0.25 \mu \mathrm{m}$ ). The mass spectrometer was scanned between $40-550$ amu and the minimum area utilised for peak integration was 300,000 ions/second. Retention time for the peaks with total ion current (TIC) higher than $3 \times 10^{6}$ ions/second were recorded and the compounds identified with mass spectral database. Only compounds with a similarity index higher than $83 \%$ were considered and further identification through standards was not attempted.

Total rainfall and mean temperature (minimum + maximum/2) data were colleted daily with pluviometer and thermometer (minimum and maximum), respectively, in the municipality of Guidoval (1999) and by "Estação Climatológica Principal" of the Federal University of Viçosa (UFV), in Municipality of Viçosa (1998-1999). Pearson's correlations $(P \leq 0.05)$ were used to evaluate the relationships of total rainfall and mean temperature, natural enemies, leaf chemical composition, leaf $\mathrm{N}$ and $\mathrm{K}$ levels and leaf trichome density with the number of A. gossypii and T. palmi.

\section{RESULTS}

Higher numbers of A. gossypii and Thrips palmi per leaf were observed in eggplants in the municipality of Viçosa $(0.58 \pm 0.37$ and $0.24 \pm$ 0.14 , respectively) and Guidoval ( $0.28 \pm 0.11$ and $0.79 \pm 0.41$, respectively) (Fig. 1). Guidoval had a rainy and hotter weather in $1999\left(23.62 \pm 1.34{ }^{\circ} \mathrm{C}\right.$ and $1,588.90 \mathrm{~mm}$, respectively) than Viçosa in $1998\left(21.67 \pm 0.79{ }^{0} \mathrm{C}\right.$ and $1,139.00 \mathrm{~mm}$, respectively) and $1999\left(20.85 \pm 0.73{ }^{\circ} \mathrm{C}\right.$ and $1,224.80 \mathrm{~mm}$, respectively) (Fig. 2). T. palmi was almost positivelly correlated with total rainfall $(\mathrm{r}=$ 0.49, $P=0.0538$ ). Eventhough without significance, $A$. gossypii seemed to be more affected by mean temperature $(\mathrm{r}=-0.31 ; P=$ 0.1134).

The main parasitoids observed in eggplant plantations of the municipalities of Viçosa were

Adialytus spp. (Hymenoptera: Braconidae) $(0.10 \pm$ 0.03/leaf) and Eulophidae (Hymenoptera) (0.06 \pm $0.02 /$ leaf). In Guidoval, only the parasitoid Adialytus spp. (0.16 $\pm 0.06 /$ leaf $)$ was found. Predators observed in Viçosa and Guidoval, respectively, were spiders [Architis (Pisauridae), Cheiracanthium inclusum (Hentz) (Miturgidae), Oxyopes spp. (Oxyopidae), Misumenops spp. (Thomisidae) and Anyphaenidae $(0.11 \pm$ 0.03/leaf and $0.23 \pm 0.09 /$ leaf); Cycloneda sanguinea (L.) and Exochomus bimaculosus Mulsant (Coleoptera: Coccinellidae) (0.01 \pm $0.01 /$ leaf and $0.30 \pm 0.16 /$ leaf) and Orius spp. (Heteroptera: Anthocoridae) $(0.01 \pm 0.01 /$ leaf and $0.01 \pm 0.01 /$ leaf $)$. Others predadors such as Chrysoperla spp. (Neuroptera: Chrysopidae) (0.01 \pm 0.01/leaf), Geocoris sp. (Heteroptera: Lygaeidae) $(0.03 \pm 0.03 /$ leaf $)$, and Aelothripidae (Thysanoptera) $(0.01 \pm 0.01 /$ leaf $)$ were observed only in Guidoval. The aphid parasitoid (Adialytus spp.) was significatively correlated with aphid populations $(\mathrm{r}=0.70, P=0.0407)$ and the spiders were significatively correlated with thrips $(\mathrm{r}=$ $0.64, P=0.0065$ ) in both localities.

No significant correlation was found $(P>0.05)$ between levels of $\mathrm{N}$ and $\mathrm{K}$, chemical leaf composition and density of trichomes (100\% non glandular) on populations of aphids and thrips in both municipalities studied (Figs. 1 and 3). 

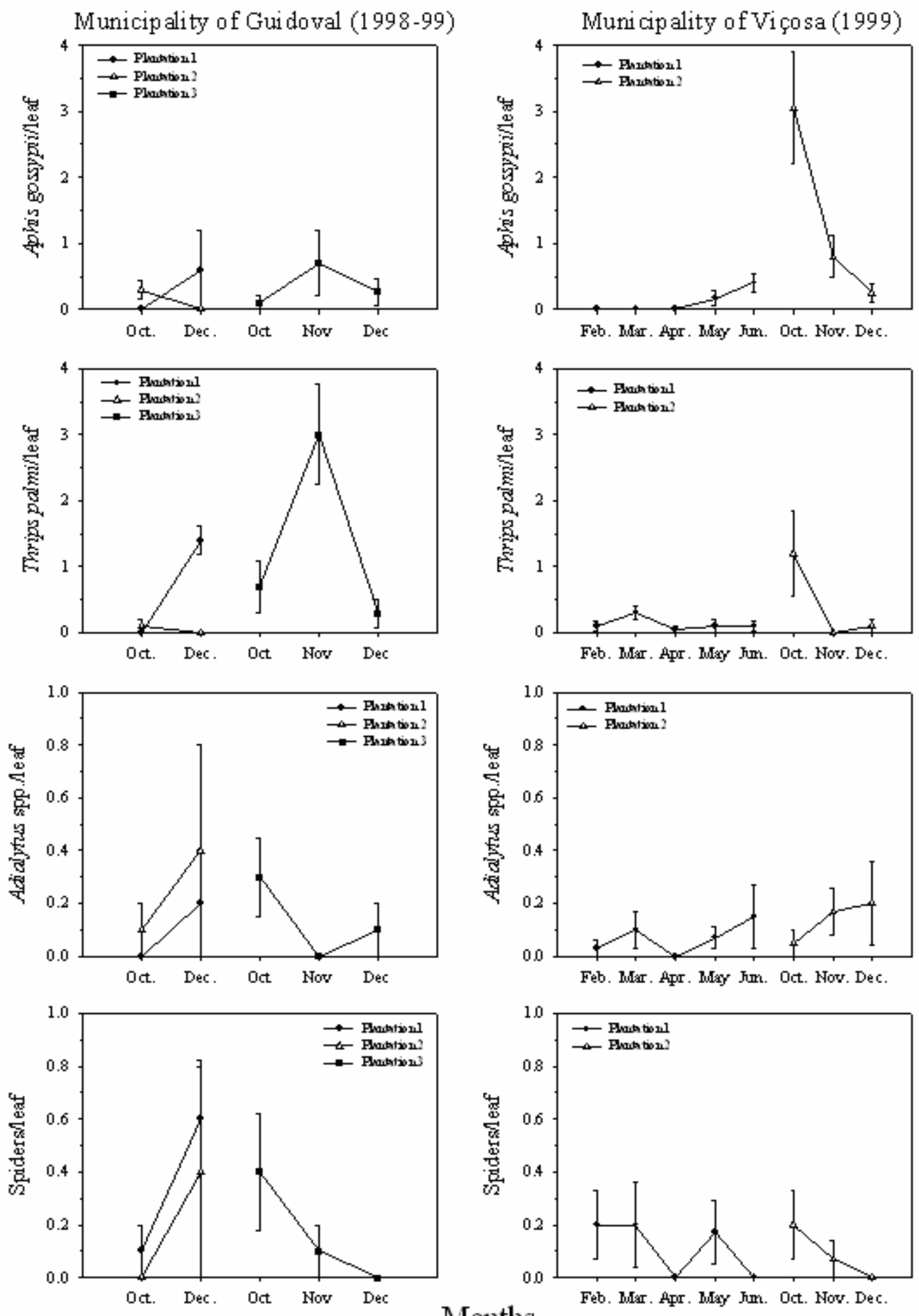

Figura 1 - Population fluctuation of Aphis gossypii/leaf, Thrips palmi/leaf, Adialytus spp./leaf and spiders/leaf in the eggplant (Solanum melongena) in the municipalities of Viçosa and Guidoval. Symbols represent mean of 40 leaves for Viçosa and 10 leaves for Guidoval, and vertical bars indicate standard errors of the mean. 

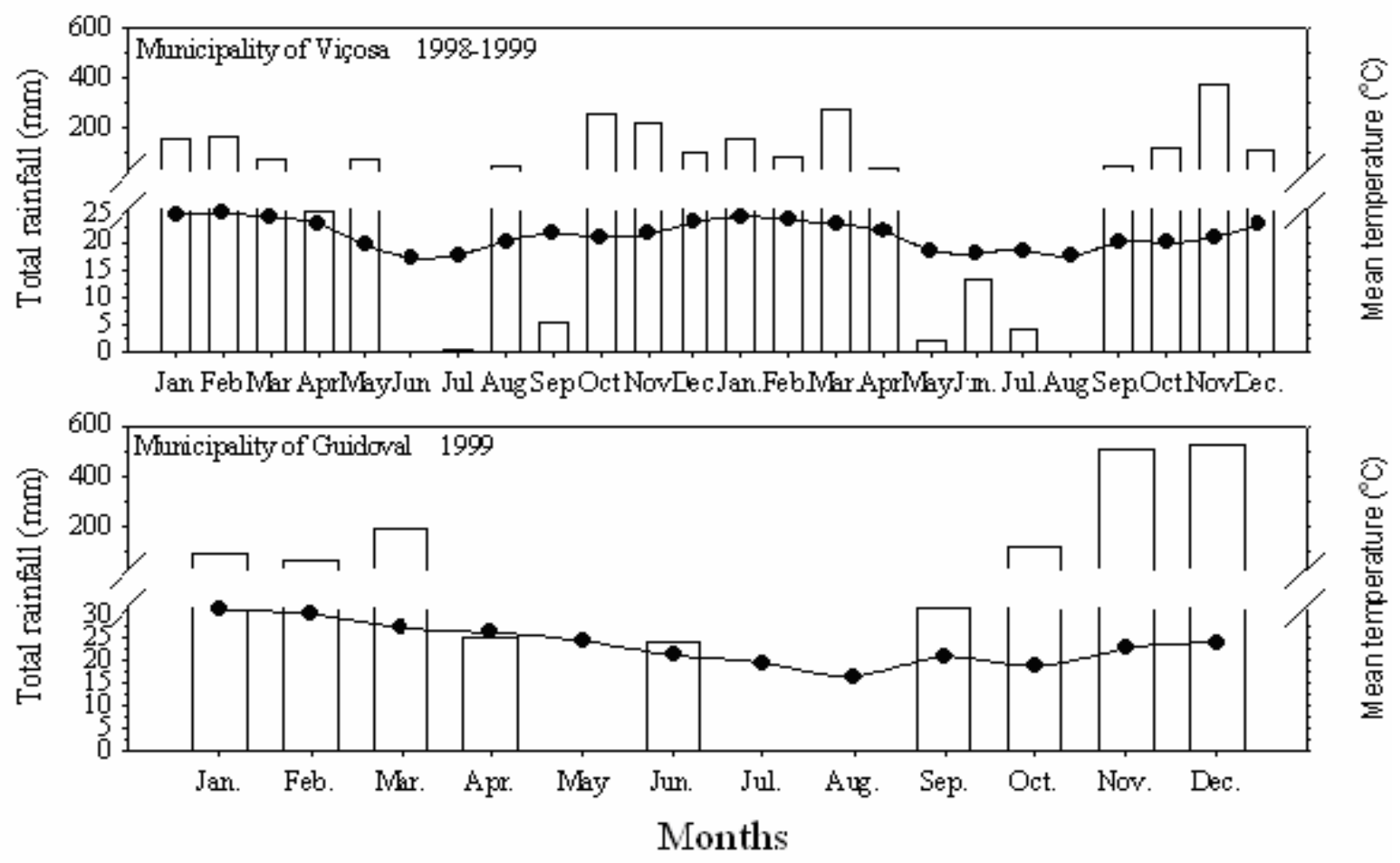

Figura 2 - Total rainfall distribution $(\mathrm{mm})$ and mean temperature (minimum + maximum/2) $\left({ }^{\circ} \mathrm{C}\right)$ in the municipalities of Viçosa (1998-1999) and Guidoval (1999). Symbols represent, in general, the rainfall accumulated and the mean temperature for 30 days.

Higher density of star trichomes $/ \mathrm{mm}^{2}$ with one vertical and four to five horizontal arms was observed in the abaxial $(5.92 \pm 0.27)$ than in the adaxial face $(2.04 \pm 0.34)$ of eggplant leaves.

No differences between faces of leaves were found for density of long simple and non ramified trichomes $(0.25 \pm 0.06)$. This last type of trichome represented about $11 \%$ of their total number.

Three peaks with retention time of 25.503, 28.292 and $48.362 \mathrm{~min}$. were recorded for the total ion current with hexane extract of $M$. solanum leaves on GC/MS analysis (Fig. 4). The peak at 25.503 was identified as palmitic/hexadecanoic acid with a similarity index (SI) of $87 \%$. The peak at 28.292 min was identified as $11,14,17$ eicosatrienoic methyl ester acid/myrcenol /1-tetradecen-3-yne/ 1,6,9-tetradecatriene /3-tetradecen-5-yne with a SI of $83 \%$, while the peak at $48.362 \mathrm{~min}$ was identified as octacosane with a SI index of $93 \%$.

\section{DISCUSSION}

A. gossypii is most important pest of eggplants in regions with milder temperature and T. palmi in those with higher temperatures. Thrips were weakly correlated with total rainfall and no correlation with temperature was observed. This showed an indirect effect of mean temperature because rainfall occurred during periods of higher temperature in this region (convective rain). High temperatures and rainfall usualy are important mortality causes of aphids in the field (Walker et al., 1984; Nakata, 1995; Picanço et al., 1997) and this factor can also regulate populations of thrips, because the rain washes nymphs and adults of this pest from eggplant leaves (Etienne et al., 1990; Kajita et al., 1996). On the other hand, temperature increase favours populations of thrips, reducing developmental period (Lorini and Dezordi, 1990; Gonçalves, 1997).

A possible explanation for the higher number of aphids in eggplant plantations of Viçosa was the presence of higher number of aphid parasitoids as Adialytus, ladybugs and Neuroptera species than 
in Guidoval. On the other hand, only the aphid parasitoid was significatively correlated with aphid populations. Parasitoids of genus Adialytus could be limiting factor for population increase of A. gossypii in eggplants in the municipalities of Viçosa and Guidoval. Natural enemies of aphids have been related in several vegetables promoting good control rates. Hooks et al. (1998) observed faster reduction on number of individuals of $A$. gossypii in zucchini due to parasite (Braconidae) with higher number of mummified aphids besides the presence of entomopathogenic fungi and coccinellid and syrphid larvae on this plant. The presence of predatory ladybugs $C$. sanguinea and Sciminus sp., Syrphidae larva (Diptera), adults of Condylostylus spp. (Diptera: Dolichopodidae), spiders and Braconidae parasitoids were showed by Miranda et al. (1998b) on tomato plants attacked by aphids, being only the ladybugs correlated with number of aphids. Higher number of thrips in eggplant plantations in Guidoval than in Viçosa could also be explained by absence of possible Eulophidae parasitoids in the first municipality.

Parasitoids Eulophidae and predators Anthocoridae have been considered the most important natural enemies of thrips in different places (Venzon et al., 1999; Funderburk et al., 2000; Tagashira and Hirose, 2001). The spiders were found during all period of eggplant cultivation and in spite of being generalists, they should receive more attention.
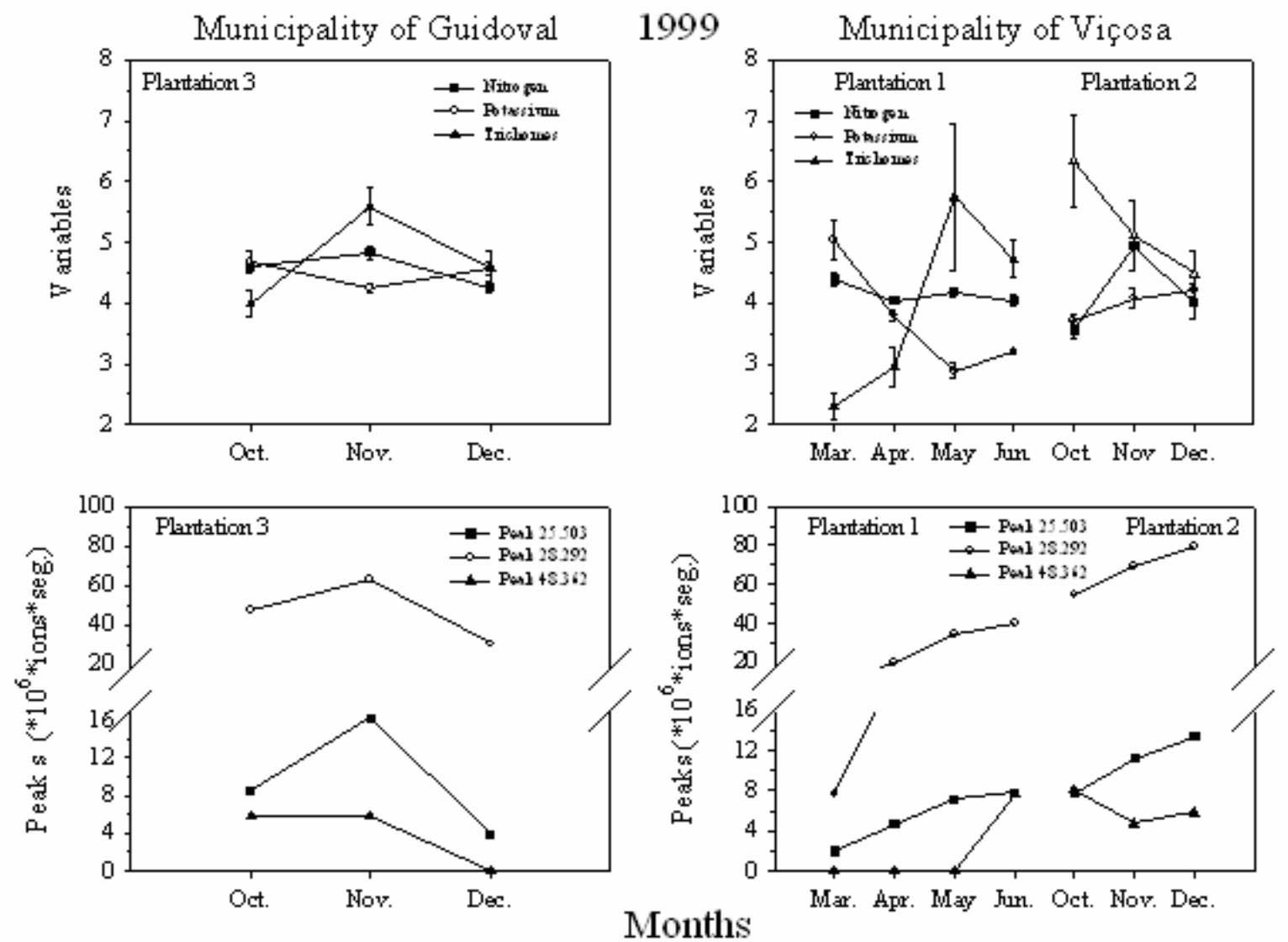

Figura 3 - Nitrogen and potassium contents (\% of dry matter), density of trichomes (adaxial +abaxial/2) per $\mathrm{mm}^{2}$ and peaks at 25.503, 28.292 and $48.362 \mathrm{~min}$ (retention time) datained from extract of eggplant (Solanum melongena) in the municipalities of Viçosa and Guidoval. Symbols represent means of three evaluations and vertical bars indicate standard errors of the mean for nitrogen, potassium and trichomes and one evaluation for peaks. 
In this study, no effect of levels of $\mathrm{N}$ or $\mathrm{K}$ on leaves of eggplant with aphids and thrips was detected, what might be explained to low variations on levels of these compounds on leaves of this plant during the experimental period. Several authors have mentioned that high $\mathrm{N}$ levels were associated with aphids and thrips infestations on lettuce, tomato and cotton (Kennedy, 1958; Brodbeck et al., 2001; Cisneros and Godfrey, 2001; Nevo and Coll, 2001) being a key factor for increasing number of aphids in cotton (Cisneros and Godfrey, 2001). However,
Leite et al. (1999) showed no effect of 100 and $300 \mathrm{mg} / \mathrm{kg}$ and 0 and $200 \mathrm{mg} / \mathrm{kg}$ of $\mathrm{N}$ and $\mathrm{K}$, respectively, in the soil on attack intensity of $M$. persicae on L. esculentum and on L. hirsutum $\mathrm{f}$. glabratum (PI 134417) in greenhouse. The increase on level of $\mathrm{K}$ was associated to reduction of pests as this chemical element was included in the synthesis of the RNA polimerase (Tanzini et al., 1993; Marschner, 1995; Leite, 1997).

Compounds observed in this work were not present in the trichomes since they were nonglandular types.

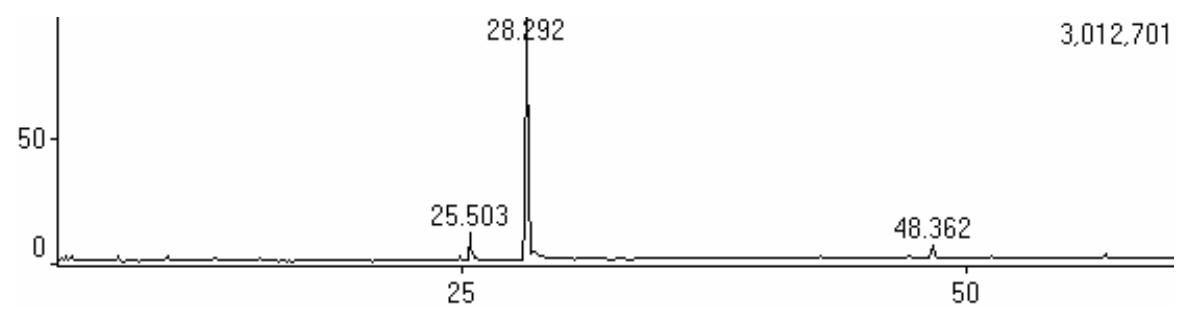

Time (minutes)

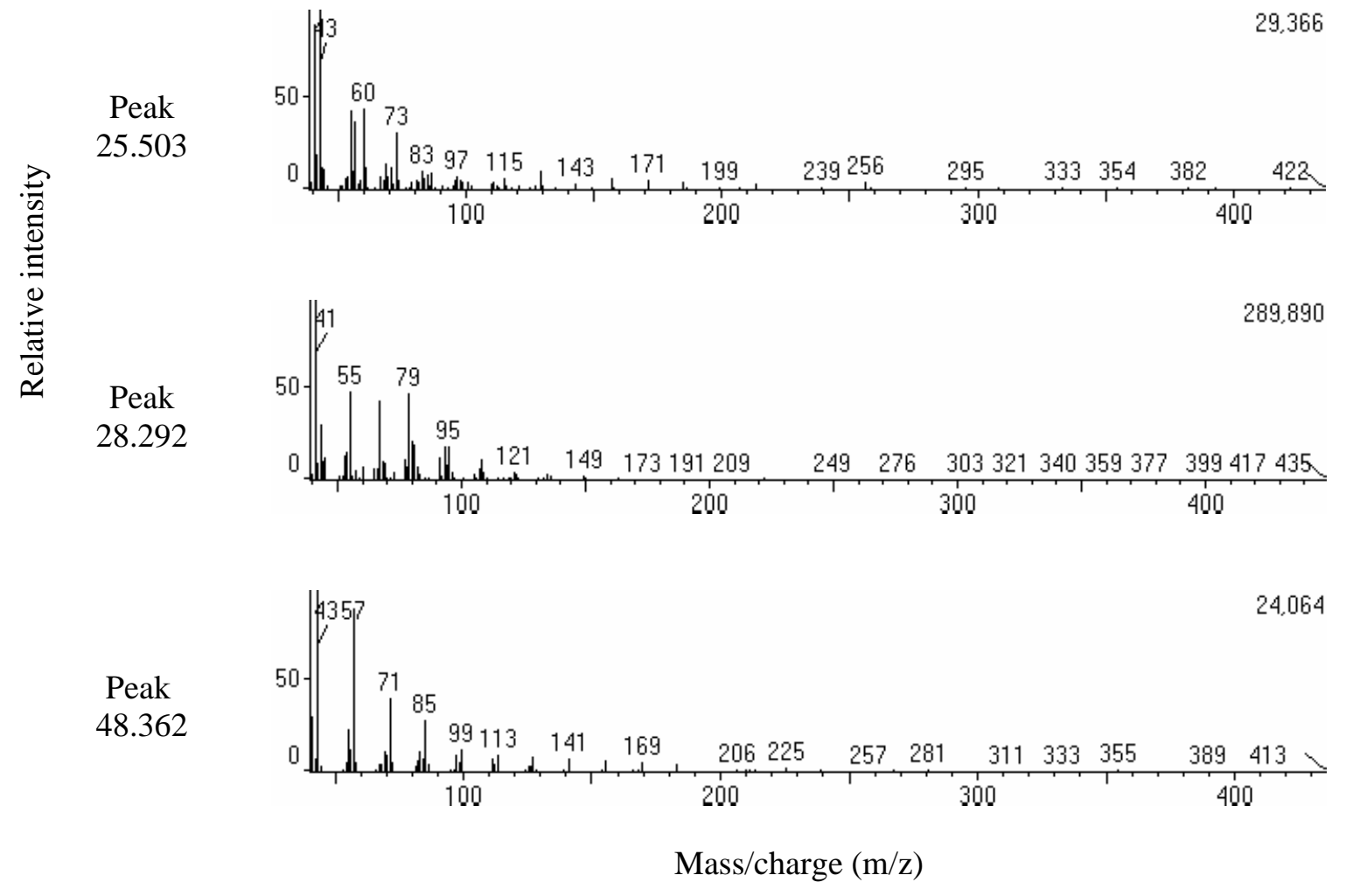

Figure 4 - Total ion current of hexane extract of eggplant (Solanum melongena) and mass spectra of peaks eluting at 25.503, 28.292 and $48.362 \mathrm{~min}$. Numbers in the upper right side of each figure represent the number of ions recorded. 
These compounds and also tricomes were not correlated with aphids and thrips populations. This could be explained by the fact that eggplant had been genetically bred for a long time aiming increasing productivity. For this reason, the eggplant could be losing compounds and glandular tricomes which played important role on the resistance to arthropods.

Eggplant plantation in regions with milder temperatures presentled higher possibilities to present problems with A. gossypii as well as in regions with higher temperature could have problems with $T$. palmi. Natural enemies, especially the parasitoid Adialytus spp. could be important controlling agents of the A. gossypii population in eggplant.

\section{RESUMO}

O objetivo deste estudo foi avaliar os efeitos de pluviosidade total, temperatura média, inimigos naturais, composição química foliar, níveis de nitrogênio e potássio foliar e densidade de tricomas na intensidade de ataque de Thrips palmi Karny (Thysanoptera: Thripidae) e Aphis gossypii (Glover) (Homoptera: Aphididae) em plantações de berinjela (Solanum melongena) em dois municípios de Minas Gerais, Brasil. Observou-se maiores números de A. gossypii e T. palmi por folha em plantações de berinjela nos municípios de Viçosa e Guidoval, respectivamente. Guidoval teve o clima mais chuvoso e quente do que Viçosa. T. palmi correlacionou positivamente com pluviosidade $(r=0,49 ; \mathrm{P}=0,0538)$ enquanto $\mathrm{A}$. gossypii parece ser mais afetado por temperatura média $(\mathrm{r}=-0,31 ; \mathrm{P}=0,1134)$. Maior número de pulgões em berinjela em Viçosa do que em Guidoval poderia ser explicado pelo maior número de inimigos naturais, tais como, Adialytus spp. (Hymenoptera: Braconidae), Cycloneda sanguinea (L.) e Exochomus bimaculosus Mulsan (Coleoptera: Coccinellidae) e Chrysoperla spp. (Neuroptera: Chrysopidae) no último município. Entretanto, somente Adialytus spp. correlacionou significativamente com pulgões. O maior número de $\mathrm{T}$. palmi em plantações de berinjela em Guidoval do que em Viçosa pode ser devido a ausência do parasitóide Eulophidae no primeiro município. As aranhas correlacionaram significativamente com esta praga em ambos os municípios.

\section{REFERENCES}

Brodbeck, B. V.; Stavisky, J.; Funderburk, J. E.; Andersen, P. C. and Olson, S. M. (2001), Flower nitrogen status and populations of Frankliniella occidentalis feeding on Lycopersicon esculentum. Entomol. Exp. App., 99, 165-172.

Butler Jr., G. D.; Henneberry, T. J.; Stansly, P. A. and Schuster, D. J. (1993), Insecticidal effects of selected soaps, oils and detergents on the sweetpotato whitefly (Homoptera: Aleyrodidae). Fla. Entomol., 76, 161-167.

Cisneros, J. J. and Godfrey, L. D. (2001), Midseason pest status of the cotton aphid (Homoptera: Aphididae) in California cotton: is nitrogen a key factor? Environm. Entomol., 30, 501-510.

Dent, D. R. (1995), Integrated pest management. London: Chapman and Hall. 356 pp.

Etienne, J.; Guyot, J. and Van Waetermeulen, X. (1990), Effect of insecticides, predation, and precipitation on populations of Thrips palmi on aubergine (eggplant) in Guadeloupe. Fla. Entomol., 73, 339-342.

Filgueira, F. A. R. (2000), Novo Manual de Olericultura. Universidade Federal de Viçosa, Viçosa. 402 pp.

Funderburk, J.; Stavisky, J. and Olson, S. (2000), Predation of Frankliniella occidentalis (Thysanoptera: Thripidae) in field peppers by Orius insidiosus (Hemiptera: Anthocoridae). Environm. Entomol., 29, 376-382.

Gallo, D.; Nakano, O.; Silveira Neto, S.; Carvalho, R. P. L.; Batista, G. C.; Berti Filho, E.; Parra, J. R. P.; Zucchi, R. A.; Alves, S. B.; Vendramim, J. D.; Marchini, L. C.; Lopes, J. R. S. and Omoto, C. (2002), Manual de entomologia agrícola. Piracicaba: FEALQ. 920 pp.

Gonçalves, P. A. S. (1997), Flutuação populacional de tripes, Thrips tabaci Lind., em cebola em Ituporanga, Santa Catarina. An. Soc. Entomol. Brasil, 26, 365-369.

Hosoda, A.; Hama, H.; Susuki, K. and Ando, Y. (1993), Insecticide resistance of the cotton aphid, Aphis gossypii Glover. III. Host preference and organophosphorus susceptibility. J. Appl. Entomol. Zoo., 37, 83-90.

Hooks, C. R. R.; Valenzuela, H. R. and Defrank, J. (1998), Incidence of pests and arthropod natural enemies in zucchini grown with living mulches. Agric., Ecos. Environm., 69, 217-231.

Jackson, M. L. (1958), Soil chemical analysis. New Jersey: Prentice Hall. 498 pp.

Johansen, D. A. (1940), Plant microtechnique. New York: McGraw Hill Book. 470 pp. 
Kajita, H.; Hirose, Y.; Takagi, M.; Okajima, S.; Napompeth, B. and Buranapanichpan, S. (1996), Host plants and abundance of Thrips palmi Karny (Thysanoptera: Thripidae), an importante pest of vegetables in Southeast Asia. J. Appl. Entomol. Zoo., 31, 87-94.

Kawai, A. (1986), Studies on population ecology of Thrips palmi Karny. XII. Analyses of damage to eggplant and sweet pepper. J. Appl. Entomol. Zoo., 30, 179-187.

Kennedy, J. S. (1958), Physiological conditions of the host plant and susceptibility to aphid attack. Entomol. Exp. Appl., 2, 50-65.

Leite, G. L. D. (1997), Efeito da idade, parte do dossel e níveis de adubação NK na resistência de Lycopersicon hirsutum f. glabratum à Tuta absoluta. MSc Thesis, Universidade Federal de Viçosa, Viçosa, Minas Gerais, Brasil.

Leite, G. L. D.; Picanço, M.; Guedes, R. N. C. and Skowronski, L. (1999), Effect of fertilization levels, age and canopy height of Lycopersicon hirsutum on the resistance to Myzus persicae. Entomol. Exp. Appl., 91, 267-273.

Lorini, I. and Dezordi, J. (1990), Flutuação populacional de Thrips tabaci Lindeman, 1888 (Thysanoptera: Thipidae) na cultura da cebola. An. Soc. Entomol. Brasi1, 9, 361-365.

Marschner, H. (1995), Mineral nutrition of higher plants. London: Academic Press. 889 pp.

Metcalfe, C. R. and Chalk, L. (1979), Anatomy of the Dicotyledons. London: Oxford University Press. $276 \mathrm{pp}$.

Miranda, M. M. M.; Picanço, M.; Leite, G. L. D.; Zanuncio, J. C. and Clercq, P. (1998a), Sampling and non-action levels for predators and parasitoids of virus vectors and leaf miners of tomato plants in Brazil. Med. Fac. Land. Univ. Gent, 63, 519-523.

Miranda, M. M. M.; Picanço, M.; Matioli, A. L. and Pallini-Filho, A. (1998b), Distribuição na planta e controle biológico natural de pulgões (Homoptera: Aphididae) em tomateiros. Rev. Bras. Entomol., 42, 13-16.

Nagai, K. (1990), Suppression effect of Orius sp. (Hemiptera: Anthocoridae) on the population density of Thrips palmi Karny (Thysanoptera: Thripidae) in eggplant in an open field. J. Appl. Entomol. Zoo., 34, 109-114.

Nakata, T. (1995), Population fluctuations of aphids and their natural enemies on potato in Hokkaido, Japan. J. Appl. Entomol. Zoo., 30, 129-138.

Nevo, E. and Coll, M. (2001), Effect of nitrogen fertilization on Aphis gossypii (Homoptera: Aphididae): variation in size, color and reproduction. J. Econ. Entomol., 94, 27-32.

Picanço, M.; Casali, V. W. D.; Oliveira, I. R. and Leite, G. L. D. (1997), Homópteros associados ao jiloeiro. Pesq. Agropec. Bras., 32, 451-456.
Sakimura, K.; Nakahara, L. M. and Denmark, H. A. (1986), A thrips: Thrips palmi Karny (Thysanoptera: Thripidae). Entomol. Circ. Fl. Dept. Agric. Consum. Serv. Div. Pl. Indus., 280, 4 pp.

Stansly, P. A. (1995), Seasonal abundance of silverleaf whitefly in Southwest Florida vegetable fields. Proc. Flo. Sta. Hortic. Soc., 108, 234-242.

Tagashira, E. and Hirose, Y. (2001), Development and reproduction of Ceranisus menes (Hymenoptera: Eulophidae), a larval parasitoid of thrips: effects of two host species, Frankliniella intonsa and Thrips palmi (Thysanoptera: Thripidae). Appl. Entomol. Zoo., 36, 237-241.

Tanzini, M. R.; Mendes, P. C. D. and Calafiori, M. H. (1993), Controle de tripes (Caliothrips brasiliensis Morgan, 1929) em feijoeiro (Phaseolus vulgaris) com potássio. Ecossistema, 18, 141-148.

Walker, G. P.; Nautl, L. R. and Simonet, D. E. (1984), Natural mortality factors acting on potato aphid (Macrosiphum euphorbiae) populations in processing-tomato fields in Ohio. Environm. Entomol., 13, 724-732.

Venzon, M.; Janssen, A. and Sabelis, M. W. (1999), Attraction of a generalist predator towards herbivoreinfested plants. Entomol. Exp. Appl., 93, 305-314.

Received: July 09, 2004; Revised: March 14, 2005; Accepted: February 09, 2006. 